\title{
SEXUAL EXPLOITATION AND ABUSE BY UN \\ PEACEKEEPERS: THE PSYCHOSOCIAL CONTEXT OF BEHAVIOUR CHANGE
}

\author{
Carol Allais \\ Department of Sociology, University of South Africa
}

\begin{abstract}
United Nations peacekeepers have been subject to allegations of serious sexual misconduct for many years. Such incidents of sexual assault perpetrated by peacekeepers have been documented over the years in a number of countries. The violation of codes of conduct, particularly regarding sexual exploitation and abuse, damages the image and credibility of a peacekeeping operation. Victims of sexual exploitation and abuse suffer sever physical and psychological consequences.The sexual exploitation of children by peacekeepers is particularly insidious. Educational interventions and training initiatives to bring about behaviour change to address sexual exploitation and abuse must take cognisance of the way in which social identities are shaped in response to the life challenges posed by the relevant social and material world in which peacekeepers find themselves.
\end{abstract}

\section{Introduction}

Human rights transgressions and abuse, whether in war or other military deployment, remain an inescapable reality. Sexual abuse in armed conflict has a long history and has always been considered normal wartime behaviour, with perpetrators acting with unreserved impunity. Perpetrators range from members of official armed and security forces, paramilitary groups, non-state armed groups to civilians, including refugees and displaced persons. ${ }^{1}$ Although the majority of victims of sexual violence are women and girls, men and boys are also targeted. In many conflicts, indigenous people or people from specific population groups are targeted for sexual violence based on their ethnicity. ${ }^{2}$ While the majority of the perpetrators of sexual exploitation and abuse (SEA) are male, there have also been reports of perpetrators being women. Humanitarian and peacekeeping personnel

Scientia Militaria, South African Journal of Military Studies,

Vol 39, Nr 1, 2011, pp. 1-15.

doi: $10.5787 / 39-1-99$ have a long history of sexual misconduct, usually in the form of sexual exploitation, sexual abuse ${ }^{3}$ and human trafficking. The notion of human security holds that a people- 
centred view of security is necessary for national, regional and global stability. Personal security, as one of the components underpinning human security, aims to protect people from physical violence, whether from the state or external states, from violent individuals and sub-state actors, from domestic abuse, or from predatory adults. $^{4}$

In this article, it is argued that explanations of why peacekeepers engage in sexual exploitation and abuse should involve an understanding of the social identities of the peacekeepers and the social conditions under which these identities are constructed. Stockdale points out that sexual behaviour is closely linked with the norms of the social groups with which we identify. ${ }^{5}$ These norms shape the boundaries of permissible behaviour and define the limits of deviance. Any efforts to bring about behaviour change must take cognisance of the way in which social identities are shaped in response to the life challenges posed by the relevant social and material world within which they find themselves.

The article commences with a discussion of the role of peacekeeping, the problem of SEA in peacekeeping missions, the consequences of SEA for missions and victims, and attempts to address the problem. A brief outline of Social Identity Theory/Self-Categorisation Theory (SIT/SCT) is provided in the second half of the article as the theoretical point of departure for behaviour change initiatives. The article concludes with some observations on training approaches and the need for more innovative interventions to prevent and respond to SEA.

\section{The changing role of peacekeeping}

Peacekeeping is defined by the United Nations (UN) as "a unique and dynamic instrument developed by the Organization as a way to help countries torn by conflict create the conditions for lasting peace". ${ }^{6}$ With the end of the Cold War, the changing strategic context for UN peacekeeping forced the organisation to shift and expand its field operations from ,traditional' missions involving strictly military tasks to complex „multidimensional' enterprises, which would ensure the implementation of comprehensive peace agreements and facilitate the laying of foundations for sustainable peace. Peacekeepers today undertake a wide variety of complex tasks, from helping to build sustainable institutions of governance, to human rights monitoring, to security sector reform, to the disarmament, demobilisation and reintegration of former combatants. ${ }^{7}$

Despite the developmental and conciliatory objectives of the organisation however, UN peacekeepers ${ }^{8}$ have been subject to allegations of serious sexual misconduct for many years. ${ }^{9}$ The potential for sexual abuse in peacekeeping operations is well recognised. The Assistant Secretary General for Peacekeeping was quoted as saying that his operating presumption is that sexual abuse is either a 
problem or a potential problem in every single one of the UN missions. ${ }^{10}$ In the past, the hypermasculine culture deriving from a predominantly male environment has produced a tolerance for extreme behaviours such as SEA and a tradition of silence. ${ }^{11}$ In 1992, allegations that UN peacekeepers were involved in cases of sexual abuse against local women were met by the infamous statement "Boys will be boys" by Yasushi Akashi, then head of the UN Transnational Authority in Cambodia. This type of thinking has been equated with the equally infamous view of Nazi Propaganda Minister, Joseph Goebbels, that "Men should be trained as warriors and women as recreation for warriors. Anything else is foolishness." 12 This view has for long exemplified prevailing official perceptions regarding cases of sexual abuse by international troops. ${ }^{13}$

\section{Sexual misconduct as potential unintended consequence of peacekeeping operations}

Sexual misconduct has been identified by Aoi, De Coning and Thakur as one of a number of unintended consequences of peacekeeping operations. ${ }^{14}$ They contend that while peace operations are considered to be an indispensible instrument in the international conflict management toolbox, the post-Cold War shift of focus and modification in the role and scope of peace operations have exposed them (especially UN operations) to a new range of what they refer to as "potential unintended consequences". Sexual and gender-based violence is seen as part of a permissive environment arising from the breakdown of law and order, socioeconomic infrastructure and socio-cultural norms in post-conflict societies where the natural checks and balances that would otherwise contain and manage potential negative effects are absent. This permissive environment is identified by Aoi et al. ${ }^{15}$ as one of the unintended consequences of peacekeeping, which they describe as those reactions that fall outside the scope of the intended responses. ${ }^{16}$ (Aoi et al point out that while no missions have failed as a result of the negative consequences they have generated, there are many whose effectiveness has been negatively affected by some of the unintended consequences they have generated. There are also some that have generated consequences far beyond specific peace operations.)

Sexual violence and abuse constitute atrocious violations of the human rights of the victims of the abuse. Regardless of the degree of overt physical force, there are severe physical and psychological consequences for the victims. Direct injuries include chronic pain, infection and infertility. Brutal rape can result in traumatic gynaecological fistula. Rape may also lead to abortion, which carries its own risk. The psychological implications are equally serious. Survivors often experience severe trauma and depression, sometimes leading to suicide. Some victims are infected with sexually transmitted diseases, including HIV. Many have little or no access to care or counselling. 


\section{The sexual exploitation and abuse of children}

The sexual exploitation of children is particularly insidious. Research into the sexual exploitation and abuse of children conducted by Save the Children in Cote D'Ivoire, Haiti and Southern Sudan in 2007 revealed cases of abuse associated with a sum total of 23 humanitarian, peacekeeping and security organisations. ${ }^{17}$ These included civil humanitarian agencies such as those delivering food and nutritional assistance, care, educational and health services, reconstruction, shelter, training, and livelihood support as well as military actors providing peace and security support. Allegations of sex with minors were reported against staff from the World Food Programme (WFP), the United Nations High Commission for Refugees (UNHCR), the United Nations Volunteers (UNV) as well as local and international NGOs. Troops associated with the UN Department of Peacekeeping Services (DPKO) were identified as a particular source of abuse in these fieldwork locations, particularly in Haiti and Cote D'Ivoire. ${ }^{18}$ The report identified "every kind of child sexual abuse and exploitation imaginable", ${ }^{19}$ including trading sex for food and other non-monetary items or services, forced sex, verbal sexual abuse, child prostitution, child pornography, sexual slavery, indecent sexual assault, and child trafficking linked with commercial sexual exploitation. The Save the Children report also identified a range of specific sexual acts being performed by children ${ }^{20}$ for staff associated with the international community. These included oral sex, penetrative sex, lesbian sexual displays, kissing and groping. ${ }^{21}$ Although coerced sex was found to be more common than forced sex, children as young as six were trading sex with aid workers in exchange for food, money and soap. In a few cases, sex was traded for luxury items such as cell phones.

Incidents of sexual assault perpetrated by UN peacekeepers have been widely documented. ${ }^{22}$ The allegations of sexual exploitation and abuse by UN peacekeepers of those they have been mandated to protect are particularly disturbing because of the unique nature of peacekeeping. The UN Security Council deploys military troops in order to protect vulnerable populations from the violence of civil conflict and the UN "should not in any way increase the suffering of vulnerable sectors of the population which has often been devastated by war or civil conflict". ${ }^{23}$ The charges of sexual misconduct, and the consequent media exposure, have undermined the credibility of the UN, its Secretary General and of peace operations as an international conflict management instrument.

\section{The risk to peacekeeping operations}

The violation of codes of conduct may damage the impartiality of missions in the eyes of the local population, which, in turn, may impede the implementation 
of its mandate. The ill discipline engendered by SEA also degrades the effectiveness of the peacekeeping operation, especially in times of crisis. Instances of sexual exploitation and abuse may also constitute violations of international humanitarian law, international human rights law, or both. A peacekeeping operation cannot legitimately advise any government on adherence to international human rights standards and legal and judicial reform if its own peacekeeping personnel are engaging in acts of sexual exploitation and abuse, including such crimes as rape.

Sexual misconduct by peacekeeping personnel can also expose both themselves and the mission to blackmail and violent retaliation, especially during times of breakdown in law and order in the country. Sexual misconduct also increases the incidence of medical problems. This includes the risk of contracting or transmitting sexually transmitted diseases and HIV/AIDS. The consequences for victims include possible psychological trauma as a result of their experiences. Babies born from liaisons between victims and peacekeepers may face stigmatisation by their families and communities, which may deprive them of economic, social and emotional support, which in turn may result in victims being driven into further exploitative relationships with peacekeepers in order to survive. ${ }^{24}$

\section{United Nations responses}

In 2002, humanitarian personnel in West Africa were accused of sexually exploiting refugee children, usually girls. Sixty-seven aid workers from more than 40 agencies were accused of offering children money, food and promises of education in exchange for sex. While not all allegations could be proved, the publicity generated by these incidences together with the recognition that there was a problem that had to be addressed, resulted in the then UN Secretary General, Kofi Annan, issuing a bulletin in 2003. The bulletin, Special measures for protection from sexual exploitation and sexual abuse (ST/SGB/2003/13) (UN, Secretary General's Bulletin 2003), characterises sexual exploitation and abuse as acts of serious misconduct and subject to disciplinary action. The bulletin sets forth several specific standards to clarify the already existing obligations of UN staff with regard to sexual exploitation and sexual abuse, and specifies that:

- acts of sexual abuse and exploitation are prohibited, and constitute serious misconduct that will be subject to disciplinary action including summary dismissal;

- sexual activity with children under the age of 18 is strictly prohibited;

- any exchange of money, employment goods or services - including any exchange of assistance due to beneficiaries of assistance - for sex is prohibited; 
- sexual relationships between UN staff and beneficiaries are based on inherently unequal power dynamics and therefore undermine the credibility and integrity of the work of the United Nations;

- United Nations staff members who suspect other UN workers must report concerns; and

- managers at all levels have a responsibility to support and develop an environment that prevents sexual exploitation. ${ }^{25}$

Concern about the involvement of UN peacekeepers in sex trafficking first became widespread in the 1990s when investigators found soldiers were customers in brothels in Bosnia and Kosovo, which relied upon women sold into forced prostitution. (One estimate suggested that up to 2000 women had been coerced into sex slavery in Kosovo. ${ }^{26}$ Hearings conducted by the US House of Representatives in 2002 revealed that members of Stabilisation Forces (SFOR) were patronising Bosnian brothels and having sex with underage girls. There were also reports of International Police Task Force officers and SFOR soldiers actually „buying' trafficked women and actively participating in the trafficking of women into prostitution by forging documents, recruiting and selling women to brothel owners. The UN Human Rights investigator, David Lamb, testified to the denial and "astonishing cover-up attempts" which extended to the highest levels of the UN headquarters. UN personnel also took with them hundreds of files regarding human trafficking when the UN mission in Bosnia turned over its duties to the European Union Police Mission at the end of 2002. ${ }^{27}$ As more incidents of abuse perpetrated by UN peacekeepers are being reported, cases have been documented in almost every UN mission and operation.

\section{Zero-tolerance policy}

A zero-tolerance policy was outlined in the bulletin for all UN personnel. Until the issuance of the 2003 Secretary's Bulletin, the UN lacked a clearly articulated policy on the matter. And even once it was issued it took many months and more adverse publicity to the UN before they started implementing the rules. ${ }^{28}$ Despite the zero-tolerance policy outlined in the 2003 bulletin, allegations of peacekeeper misconduct arose in the Democratic Republic of Congo (DRC). A number of media reports in 2004 alleged 150 allegations of sexual assault by MONUC (United Nations Organization Mission in the Democratic Republic of the Congo) peacekeepers, including 68 cases of rape, paedophilia and prostitution. These reports also alleged cases of torture, the pornographic videotaping of Congolese women and children by UN peacekeepers and the fathering of ,peacekeeping babies'. ${ }^{29}$ One of the cases investigated was that of a French logistics employee who videotaped himself torturing and abusing naked girls. ${ }^{30}$ Most of the allegations involved peacekeepers from Pakistan, Uruguay, Morocco, Tunisia, South 
Africa and Nepal. ${ }^{31}$ The allegations of peacekeeper misconduct in the DRC were aggravated by reports of peacekeepers interfering with the investigation, paying or offering to pay witnesses to change their testimony, threatening investigators and refusing to identify colleagues who were suspected of offences. ${ }^{32}$

The international media attention arising from the allegations of abuses by MONUC peacekeepers in the DRC led to the then Secretary General of the United Nations, Kofi Annan, commissioning an investigation. This investigation was headed by Prince Zeid Ra'ad Zeid Al Hussein, former civilian peacekeeper, permanent representative of Jordan to the United Nations Security Council and special advisor on sexual exploitation and abuse by UN peacekeeping personnel. An analysis of the problem of SEA was lead by the special advisor and the ensuing report, Comprehensive review of the whole question of peacekeeping operations in all their aspects $(\mathrm{A} / 59 / 710),{ }^{33}$ released in March 2005, represents the first comprehensive analysis of the problem of sexual abuse and exploitation by United Nations peacekeeping personnel. The major finding of the report was possibly that there was little if any compliance with the 2003 policy against sexual exploitation.

The Comprehensive review found, inter alia, that peacekeepers had enticed desperate women and children to engage in sexual acts for a pittance of money or a small piece of food - girls as young as 10 years old were lured to have sex for a cup of milk, a few eggs, peanut butter, a dollar. Girls were sometimes given money or food after being raped to make the intercourse appear consensual. These crimes were widespread and ongoing. Beyond the sexual crimes, it was also noted that there was a perception that "whistleblowers would not be protected" and there was a failure of contingent commanders to cooperate with the investigation. ${ }^{34}$ The final report contained extensive recommendations for top-down reform of the UN system to address problems of sexual misconduct by peacekeepers. The 2005 UN General Assembly endorsed and broadened Prince Zeid's recommendations, making them applicable to civilian as well as military personnel.

\section{Impunity as a major contributing factor}

Taking action against alleged perpetrators is, however, beset with difficulties. Allred highlights some factors identified by the Comprehensive review that contribute to the problem. ${ }^{35}$ A major underlying problem is the limited control that the UN has over individual peacekeepers. UN staff is a small minority of the membership of a peacekeeping mission. Most peacekeepers are soldiers on loan from troop-contributing countries (TCCs). With respect to them, the UN has no disciplinary authority. They serve under the operational control of their own national establishments and are subject to discipline only by their national authorities. ${ }^{36} \mathrm{~A}$ further problem is that many incidents involved personnel from other agencies. In addition, in most situations, UN personnel have enjoyed immunity from local 
jurisdictions and have been subject only to their home country's national laws. Laws differ from country to country and certain acts and practices may be legal in one place while they constitute a serious crime in another jurisdiction.

There is also a perception among peacekeepers that they are immune to prosecution for crimes they may commit while being deployed. Allred points out that in many cases this is true. ${ }^{37}$ When a TCC supplies peacekeeping soldiers to the $\mathrm{UN}$ it does so under a memorandum of agreement (MOA) that reserves its right to discipline its own forces. The UN then enters into a status of forces agreement with the host nation where the peacekeepers will be deployed, under which the host nation waives jurisdiction over peacekeepers for violations of host-nation law. As a consequence, the TCC has exclusive jurisdiction to punish its soldiers and the host nation has none. The lack of host nation jurisdiction gives these troops de facto immunity from prosecution there.

A peacekeeping operation can have up to five categories of personnel, e.g. military personnel, UN volunteers, civilian police and military observers, each with a different legal status and level of immunity. Military personnel, who comprise the great majority of peacekeepers, are subject only to the jurisdiction of the TCC. Consequently, their grant of actual immunity is limited to official duty acts, but their immunity from local law is complete. Several problems make TCCs unlikely to actually exercise jurisdiction over their troops with the result that many crimes committed by deployed peacekeepers simply go unpunished.

TCCs are often reluctant to take action on the basis of the UN's procedures. TCCs complain that evidence gathered by mission boards of inquiry and in prior preliminary investigations is either not sufficient under their national law for use in subsequent judicial or court martial proceedings or has not been gathered in a manner required by their law. Often the TCC will not get the entire board of documentation because of a UN policy of not releasing documents that could be used against the organisation by third parties. Peacekeeping missions do not have available, on a routine basis, expert personnel to assist in their investigations, nor do they have an expert prosecutor from the TCCs concerned who could advise on the requirements for subsequent action. ${ }^{38}$

The UN has abandoned the past practice of requiring TCCs to commit to exercising their jurisdiction over errant troops. This leaves the TTC with the right but not the obligation to even consider disciplinary action. If the TCC exercises its jurisdiction to discipline troops who commit crimes abroad, this arrangement will work well, but TCCs are unlikely to actually exercise jurisdiction over their troops so many crimes committed by deployed peacekeepers simply go unpunished. TCCs are often embarrassed by reports that their troops committed crimes abroad and are inclined to keep criminal charges such as human trafficking, rape and paedophilia as 
quiet as possible. Even when TCCs are conscientious and hold their troops accountable they often find the criminal investigations against their troops are inadequate or incomplete or they fail to collect evidence in a manner compliant with TCC law.

In May 2007, the former US Ambassador John R Miller claimed that, despite the efforts and recommendations made in the 2005 Comprehensive review, little had been done to prevent or punish these cases. ${ }^{39}$ Addressing the appalling levels of abuse against children, Jasmine Whitbread, chief executive of Save the Children UK observes,

In the last few years, a wide range of technical guidance, instruments, initiatives and policies have been produced by UN agencies, NGOs and others. Welcome as these are, statements of principle and good intent have yet to be converted into really decisive and concerted international action. ${ }^{40}$

Stecklow and Lauria point out that, several years after the United Nations implemented a zero-tolerance policy for sexual misconduct for its peacekeepers, the organisation is still struggling to persuade member states to investigate and discipline accused solders. ${ }^{41}$ Interviews and UN documents reveal that the problem continues and is, in fact, rising. The lack of action can be ascribed to both TCCs and the United Nations itself. The record of TCCs in addressing matters of SEA has been very mixed. Many troop-contributing countries are still slow to take appropriate measures, both preventative (consisting of training of troops prior to deployment) and punitive (where personnel are repatriated because of misconduct). Troop contributors have also been slow in accepting the need for training and enforcement of the uniform designed rules due to cultural difference in the acceptance of certain types of behaviour. ${ }^{42}$ While TCCs have reported disciplining 75 peacekeepers for sexual misconduct over the past three years, records show that most of the time nations do not even respond to UN requests for information about their investigations or disciplinary actions. In 2009, from 82 requests for information about sexually related investigations or their outcomes, only 14 replies were forthcoming. ${ }^{43}$ A 2007 vote in the General Assembly prevents the UN from taking the lead role in investigating wrongdoing by peacekeepers; that responsibility falls with the TCCs themselves.

\section{Training and gender mainstreaming as behaviour change initiatives}

While sexual contact by peacekeeping troops and UN civilian personnel with local populations has usually been tolerated either implicitly or explicitly, in the modern era, the perception of the problem is gradually changing. ${ }^{44}$ The impunity 
with which the abusers of vulnerable populations operate is increasingly being challenged and addressed.

The negative publicity engendered by revelations of continued sexual exploitation and abuse by peacekeepers has generated a range of endeavours to prevent and respond to the problem. Investigations into allegations of misconduct by missions have given rise to a number of recommendations (see, for example, Rasmussen). ${ }^{45}$ Comprehensive training and gender mainstreaming into peacekeeping operations are among the initiatives to bring about behaviour change. Since 2005, training on preventing sexual exploitation and abuse has been mandatory for all personnel on arrival at a UN peacekeeping mission. The UN Conduct and Discipline Unit (CDU) identifies training needs in field missions and supports the development of a community of practice on conduct and discipline training. SEA and the consequences thereof, is one of the topics included in training modules. Missionbased awareness-raising initiatives also form part of the strategies of the Conduct and Discipline Teams (CDTs) to prevent SEA. Awareness-raising measures comprise poster campaigns, newsletters, brochures, websites and radio broadcasts. Target audiences include host populations, local government officials, civil society organisations, international organisations and non-governmental organisations. ${ }^{46}$

Educational interventions still rely largely on traditional information-based awareness programmes such as video tapes, lectures and training manuals, designed to impart information to a passive target audience. Campbell points out that the conceptual underpinning of many information-based educational programmes is the KAP (knowledge-attitudes-practices) model. ${ }^{47}$ According to this model, behaviour is determined by an individual's knowledge and attitudes. Within this framework, information-based education programmes seek to change people's behaviours through providing them with information or knowledge about the dangers or consequences of particular kinds of behaviour. Campbell argues that information alone does not bring about consistent changes in behaviour. ${ }^{48}$ Even people with relatively high levels of knowledge indulge in high-risk behaviours. Factual knowledge is merely one determinant of behaviour. A challenge to affecting changes in sexual behaviour is to develop understandings of other co-determinants of behaviours and to develop more innovative attempts to bring about behaviour change.

\section{Social Identity Theory/Self-Categorisation Theory}

Social Identity Theory/Self-Categorisation Theory (SIT-SCT) holds that the social self consists of a loose association of self-categorisations or group memberships. ${ }^{49}$ Theorists in this tradition have tended to focus much of their attention on the psychological processes involved in identity formation, while paying less attention to the content of specific identities or the role played by day-to- 
day life situations in the shaping of identities. Subsequent development of the theory has focused on the way in which such cognitive and motivational processes are structured within dynamically changing social contexts. ${ }^{50}$

It has been suggested that different group memberships are associated with different sets of „recipes for living' and are shaped in the context of particular ,"life challenges'. Recipes for living consist of a) sets of behavioural possibilities and constraints, and b) repertoires of interpretive frameworks through which all behaviour and experiences are mediated. In this model, identity is never static, but constantly constructed and reconstructed in response to the life challenges posed by the relevant social and material worlds. The concept of life challenges highlights the situation-dependent and context-specific nature of social identities. Identities are a socially negotiated and flexible product, constructed in dynamic interaction with those in our surroundings. ${ }^{51}$

\section{Conclusion}

Programmes that aim to change people's behaviour need to be informed by understandings of the way in which behaviours are shaped by socially negotiated identities within particular social contexts. Asking people to change their behaviour will have little effect because it ignores the broader social context of masculine and feminine identities, which makes the negotiation of behaviour change a complex process. The challenge facing the designers of training material is that of designing creative and innovative programmes that go beyond providing information only. Peer education programmes have proved successful interventions to bring about behaviour change (particularly in the field of HIV/AIDS). Peer education is based on the fundamental social psychological principle that people are more likely to change their behaviour if they perceive that their peers are also committed to behaviour change. ${ }^{52}$ Peer education is conducted in situ by selected members of the team who receive basic training as well as training on how to facilitate debate in group settings. In terms of the social identity framework, such programmes are successful in changing behaviour because they provide a context in which individuals are given space to refashion their social and sexual identities in a collective way. Campbell contends that in such contexts, people play an active role in debating the possibilities of alternative recipes for living, rather than being passive recipients of impersonally presented information. ${ }^{53}$ These processes operate at the group rather than the individual level in changing people's group-linked sense of previously taken-forgranted behaviour through the collective renegotiation of social and sexual identities. Such programmes provide a context for the transformation of grouplinked recipes for living rather than seeking to alter individual behaviours through the mere provision of information. 
Acknowledgement: The author acknowledges Catherine Campbell whose work on HIV transmission on the South African Gold mines provided the impetus for this article.

\section{Endnotes}

${ }^{1}$ Bastick, M, Grimm, K \& Kunz, R. Sexual violence in armed conflict: Global overview and implications for the security sector. Geneva: Geneva Centre for the Democratic Control of Armed Forces, 2007, 14.

${ }^{2}$ Ibid.

3 The terms ,,sexual exploitation' and ,sexual abuse' are used to distinguish those who are physically forced to have sex and those who are coerced into it owing to a lack of alternative survival tactics or through ignorance of their rights. The bulletin defines ,sexual exploitation' as “any actual or attempted abuse of a position of vulnerability, differential power, or trust for sexual purposes, including, but not limited to, profiting monetarily, socially or politically from the sexual exploitation of another” and ,sexual abuse' as "the actual or threatened physical intrusion of a sexual nature, whether by force or under unequal or coercive conditions" (UN General Assembly. A comprehensive strategy to eliminate future sexual exploitation and abuse in United Nations peacekeeping operations. Report to the UN Special Committee on Peacekeeping Operations (A/59/710). 14 February 2005, 7 8).

${ }^{4}$ UN Development Programme (UNDP). Human Development Report. New York: UNDP, 1994.

${ }^{5}$ Stockdale, J. "The self and media messages: Match or mismatch". In Markova, I \& Farr, R (eds), Representations of health, illness and handicap, London: Harwood, 1995, 46.

${ }^{6}$ United Nations. UN peacekeeping multimedia information. $<$ http://www.sandiegoaccountantsguide.com/library/UN-peacekeeping.ph> Accessed on 14 June 2010.

${ }^{7}$ United Nations. United Nations peacekeeping. $<$ http://www.un.org/en/peacekeeping > Accessed on 5 May 2010.

${ }^{8}$ Most peacekeeping operations are established and implemented by the UN itself, with troops serving under UN operational control. In these cases, peacekeepers remain members of their respective armed forces, and do not constitute an independent „UN army’, as the UN does not have such a force. In cases where direct UN involvement is not considered appropriate or feasible, the UN Security Council authorises regional organisations such as the North Atlantic Treaty Organization (NATO), the Economic Community 
of West African States (ECOWAS) or coalitions of willing countries to undertake peacekeeping or peace-enforcement tasks. The UN is not the only organisation to have authorised peacekeeping missions. Non-UN peacekeeping forces include the NATO mission in Kosovo and the Multinational Force and Observers on the Sinai Peninsula.

${ }^{9}$ Official UN statistics show a higher incidence of allegations reported against peacekeeping forces than that any other UN staff (United Nations. Annual Reports. New York, 2005, 2006, 2007).

${ }^{10}$ Martin, S. Must boys be boys? Ending sexual violence and abuse in UN peacekeeping missions. Washington, DC: Refugees International, 2005.

11 Ibid.

${ }^{12}$ Kesic, V. "The status of rape as a war crime in international law: Changes introduced after the wars in the former Yugoslavia and Rwanda". MA thesis, New School University, 2001.

${ }^{13}$ Ballesteros, A. "Trafficking in human beings and international peacekeeping missions: The 2004 NATO THB policy”. Connections 6/3. 2007. 125.

${ }^{14}$ Aoi, C, De Coning, C \& Thakur, R. "Unintended consequences of peacekeeping". CIPS Electronic Briefing Paper No. 56/2007.v. 2007. $<$ https://www.cips.up.ac.za/indexphp?ebriefinglist+2089> Accessed on 22 May 2010.

15 Ibid.

${ }^{16}$ Aoi et al. (2007) point out that firstly, unintended consequences need to be distinguished from a failure to achieve intended consequences. Secondly, unintended consequences need to be distinguished from the ,mixed-motive' phenomenon in intervention decisions. While states participating in peace operations may have motives for supporting such operations other than those stated in the formal mandate of the operation, such mixed motives are not considered to be unintended consequences of peace operations. They may, however, cause or aggravate unintended consequences.

${ }^{17}$ Csaky, C. No one to turn to: The under-reporting of child sexual exploitation and abuse by aid workers and peacekeepers. London: Save the Children UK, 2008.

${ }^{18}$ Ibid. pp. 8-9.

${ }^{19}$ Ibid. p. 5.

${ }^{20}$ It is important to note that all forms of sex with children below the age of consent are illegal. A child cannot be considered to have voluntarily taken part in a sexual act, and all forms of penetrative sex with a child are rape.

${ }^{21}$ Csaky, op. cit. p. 5. 
22 Jennings, KM. Protecting whom? Approaches to sexual exploitation and abuse in UN peacekeeping operations. Oslo: FAFO, 2008; Rehn, E \& Johnson Sirleaf, E. Women, war and peace: The independent experts' assessment of the impact of armed conflict on women and women's role in peacekeeping. New York: UNIFEM, 2002.

${ }^{23} \mathrm{UN}$ General Assembly. Comprehensive review of the whole question of peacekeeping operations in all their aspects. (A/59/710). 24 March 2005, 8.

${ }^{24}$ Ibid. p. 9.

${ }^{25}$ UN Secretary General's Bulletin. Special measures for protection from sexual exploitation and abuse. (ST/SGB/2003/13). 22 May 2003.

${ }^{26}$ Bowcott, O. Report reveals shame of UN peacekeepers. 25 March 2005. $<$ http://www.guardian.co.uk/world/2005/mar/25/unitednations $>$ Accessed on 24 February 2009.

${ }^{27}$ Allred, KJ. "Peacekeepers and prostitutes: How deployed forces fuel the demand for trafficked women and new hope for stopping it". Armed Forces and Society 33/1. 2006. 7.

${ }^{28}$ UN Security Council Report. Sexual exploitation and abuse by UN peacekeeping personnel. Update Report No. 3. 20 February 2006.

${ }^{29}$ Allred, op. cit. p. 5.

${ }^{30}$ Notar, SM. "Peacekeepers as perpetrators: Sexual exploitation and abuse of women and children in the Democratic Republic of the Congo". American University Journal of Gender, Social Policy and the Law 14/2. 2006. 413.

${ }^{31}$ Allred, op. cit. p. 5.

${ }^{32}$ Ibid. p. 5.

${ }^{33}$ UN General Assembly. A comprehensive strategy to eliminate ... op. cit.

${ }^{34}$ Allred, op. cit. p. 5.

${ }^{35}$ Ibid. pp. 7-8.

${ }^{36}$ Ibid. p. 7.

${ }^{37}$ Ibid. p. 8.

${ }^{38}$ UN General Assembly. Report of the Secretary General on the activities of the Office of Internal Oversight Services into allegations of sexual exploitation and abuse in the United Nations organization mission in the Democratic Republic of the Congo. (A/59/661). 5 January 2005.

${ }^{39}$ Defeis, EF. "UN peacekeepers and sexual abuse and exploitation: An end to impunity”. Washington University Global Studies Law Review 7/2. 2008. 194.

${ }^{40}$ Csaky, op. cit. p. v.

${ }^{41}$ Stecklow S \& Lauria J. "UN mum on probes of sex-abuse allegations". Wall Street Journal. 21 March 2010. 
${ }^{42}$ UN Security Council Report, op. cit.

${ }^{43}$ Stecklow \& Lauria, op. cit.

${ }^{44}$ Ballesteros, op. cit. p. 25.

${ }^{45}$ Rasmussen, S. "MONUC. Sexual exploitation and abuse: End of Assignment Report”. Peacekeeping Resources Hub. 2005.

$<\mathrm{http}$ ://www.peacekeepingbestpractices.unlb.org/pbps $>$ Accessed on 15 December 2010.

${ }^{46}$ UN Conduct and Discipline Unit. UN Strategy.

$<$ http://cdu.unlb.org/UNStrategy/Prevention.aspx $>$ Accessed on 15 December 2010.

${ }^{47}$ Campbell, C. "Migrancy, masculine identities and AIDS: The psychosocial context of HIV transmission on the South African gold mines". Social Science \& Medicine 45/2. 1997. 273.

${ }^{48}$ Ibid. p. 274.

${ }^{49}$ Spears, R. "The interaction between the individual and the collective self: Selfcategorization in context". In Sedikides, C \& Brewer, MB (eds), Individual self, relational self, and collective self: Partners, opponents or strangers? Philadelphia, PA: The Psychology Press, 2001; Tajfel, H. Human groups and social categories: Studies in social psychology. Cambridge: Cambridge University Press, 1981; Turner, JC, Hogg, MA, Oakes, PJ, Reicher, SD \& Wetherell, MS. Rediscovering the social group: A self-categorization theory. Oxford: Blackwell, 1987.

${ }^{50}$ Campbell, C. "The social identity of township youth: An extension of social identity theory (Part 1)". South African Journal of Psychology 25/3. 1995. $160-167$.

${ }^{51}$ Campbell, "Migrancy, masculine identities and AIDS...”, op. cit. p. 274.

${ }^{52}$ Lewin, K. "Group decisions and social change". In McCaby, E (ed), Readings in social psychology, New York: Holt, Reinhart and Wilson, 1958.

${ }^{53}$ Campbell, "Migrancy, masculine identities and AIDS...", op. cit. p. 280. 